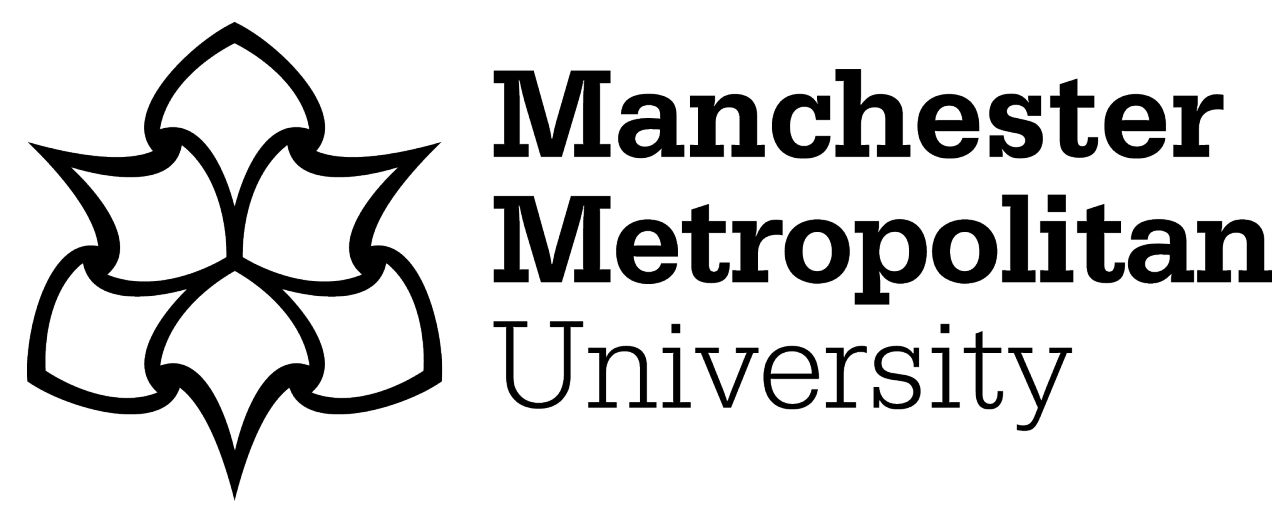

Pulvirenti, Rossella ORCID logoORCID: https://orcid.org/0000-0001-58597215 and Abrusci, Elena (2019) Prosecuting Trafficking Crimes for Sexual Exploitation in Times of Conflict: Challenges and Perspective. Journal of Trafficking and Human Exploitation, 3 (1). pp. 97-120. ISSN 2452-2775

Downloaded from: https://e-space.mmu.ac.uk/627986/ Version: Accepted Version

Publisher: Paris Legal Publishers

DOI: https://doi.org/10.7590/245227719x15476235096562

Please cite the published version 


\title{
Prosecuting Trafficking Crimes for Sexual Exploitation in Time of Conflict: Challenges and Perspective
}

\author{
Dr Rossella Pulvirenti \\ School of Law, Liverpool John Moores University \\ Elena Abrusci \\ School of Law, University of Essex
}

\begin{abstract}

\section{Introduction}

In his 2018 Report on conflict-related sexual violence (2018 Report), the United Nations (UN) Secretary-General urged the international community to address conflict-related sexual violence (CRSV), emphasising the nexus between CRSV and trafficking in persons for sexual exploitation in time of conflicts (hereinafter, trafficking). ${ }^{1}$ Taking inspiration from the 2018 Report, this article aims to study the nexus between CRSV and trafficking from an accountability point of view.

The decision to focus on this specific aspect is dictated by several factors. The Palermo Protocol, which provides the first international definition of the crime of trafficking, includes prosecution, together with prevention and protection, within its 'three-P strategy' to combat trafficking. ${ }^{2}$ Similarly, ensuring an accountability system can be considered relevant for other crimes, such as CRSV. Scholars agree that prosecution in times of war plays an important deterrent effect. ${ }^{3}$ Furthermore, trafficking in time of peace is considered a low-risk but highprofit crime because, while profits are huge, in absence of robust criminal justice responses, traffickers are hardly ever prosecuted. ${ }^{4}$ If these circumstances make trafficking a very remunerative business in times of peace, this practice is considered even more attractive in the context of a conflict. As the Secretary-General highlighted, certain armed groups not only traffic women and girls internally and across the borders for the purpose of sexual exploitation, but also carry out several conflict-related acts of sexual violence during their raids. ${ }^{5}$ Scholars believe that perpetrators of CRSV are often not prosecuted because of the difficulty to gather evidence during the investigation and the inability of linking CRSV to high-ranking accused. ${ }^{6}$
\end{abstract}

\footnotetext{
${ }^{1}$ Report of the Secretary General on conflict-related sexual violence, S/2018/250, 23 March 2018 (hereinafter 2018 Report).

2 Protocol to Prevent, Suppress and Punish Trafficking in Persons, Especially Women and Children, supplementing the United Nations Convention against Transitional Organized Crime, GA Res. 55/25, Annex II, UN GAOR, 55th Sess. Suppo, No. 49 at 53, UN Doc A/45/49 (Vol. I) (2001), done 15 November 2000, entered into force 25 December 2003 (hereinafter Palermo Protocol).

${ }^{3}$ A. Payam, 'Beyond Impunity: Can International Criminal Justice Prevent Future Atrocities?' American Journal of International Law 95(1) (2001): 7-31; J. Klabbers, 'Just Revenge? The Deterrence Argument in International Criminal Law' Finnish Yearbook of International Law 12 (2001): 249-267; D. McGoldrick, 'The Permanent International Criminal Court: An End to the Culture of Impunity?' Criminal Law Review (1999): 627-655.

${ }^{4}$ D. M. Hughes, 'The "Natasha" trade: The transnational shadow market of trafficking in women', Journal of International Affairs 53(2) (2000): 1-18; E. M. Wheaton, E. J. Schauer \& T. V. Galli, 'Economics of human trafficking', International Migration 48(4) (2010): 114-141.

${ }^{5}$ Palermo Protocol, paras 16, 18, 33.

${ }^{6}$ A. De Brouwer, 'The Importance of Understanding Sexual Violence in Conflict for Investigation and Prosecution Purposes', Cornell International Law Journal 48(3) (2015): 113, 125-129; P. Viseur-Sellers, 'Gender Strategy is Not a Luxury for International Courts', Amsterdam University Gender Social Policy and the Law 17 (2009): 301 -
} 
Since these two types of crimes are deeply intertwined, it is clear that impunity for CRSV allows the sexual trafficking market to flourish, and vice versa. Thus, prosecuting those responsible for CRSV protects potential trafficking victims because it discourages the perpetrators from 'pursuing their business'.

The first necessary step to fight the culture of indifference towards both CRSV and trafficking and to ensure an adequate prosecution is to properly criminalise these acts. The scholarly debate on this point is very limited. ${ }^{7}$ Thus, Part I of this article aims to assess domestic legislations and enforcement tools available in the 13 countries in conflict identified by the 2018 Report: Afghanistan, Central African Republic (CAR), Colombia, Democratic Republic of the Congo (DRC), Iraq, Libya, Mali, Myanmar, Somalia, South Sudan, Sudan (Darfur), Syria and Yemen.

In support of the argument according to which CRSV is not adequately addressed at the national level because domestic shortfalls are worsened during war-times, this article suggests that CRSV and trafficking should be prosecuted at the international level. Part II of this article explores the international dimension of CRSV and trafficking focusing on two different issues. First, it analyses whether the ICC has jurisdiction over the countries where the SecretaryGeneral noticed a deep nexus between CRSV and trafficking. Second, it highlights that, while CRSV is within the subject matter of the ICC, the ability of the ICC to investigate and prosecute trafficking crimes is not obvious. In conclusion, it advocates a modification of the Rome Statute to introduce the crime of trafficking as a separate crime from slavery.

\section{CRSV and Trafficking as National Crimes}

In his 2018 Report, the Secretary-General described the term 'conflict-related sexual violence' as including crimes such as 'rape, sexual slavery, forced prostitution, forced pregnancy, forced abortion, enforced sterilization, forced marriage and any other form of sexual violence of comparable gravity perpetrated against women, men, girls or boys that is directly or indirectly linked to a conflict'. ${ }^{8} \mathrm{He}$ also provides a definition for 'trafficking in persons when committed in situations of conflict for the purpose of sexual violence' indicating that this set of crimes can be considered as a subgroup of the previous category.

However, this article departs from this definition, opting for the more structured and thorough definition of trafficking provided by the Palermo Protocol, underlying the element of movement and prescinding from sexual violence. This definition informs the assessment of the domestic legislation proposed in the following section, which explores how the 13 countries under analysis are facing CRSV and trafficking in the context of conflict through their domestic criminal law framework.

\subsection{Screening of Domestic Legal Framework}

The body of law that applies during armed conflicts is generally known as international humanitarian law (IHL). However, since IHL was developed to protect civilians from the hostilities and sets the limits on the methods of warfare, it is very difficult to find provisions

25; M. Marcus, 'Investigation of Crimes of Sexual and Gender-Based Violence Under International Criminal Law' in Sexual Violence as an International Crime: Interdisciplinary Approaches ed A de Brouwer et al. (Intersentia, 2013): 211-42.

${ }^{7}$ A. B. Hourge \& K. Lohne, 'End Impunity! Reducing Conflict-Related Sexual Violence to a Problem of Law', Law \& Society Review 51(4) (2017). See also the OSCE, Combating Impunity for Conflict-Related Sexual Violence in Bosnia and Herzegovina: Progress and Challenges (June 2015) and Towards Justice for Survivors of Conflict-Related Sexual Violence in Bosnia and Herzegovina: Progress before Courts in BiH 2014-2016.

82018 Report, para 2. 
which prohibit or, even, criminalise trafficking. ${ }^{9}$ For this reason, this paper focuses on the Palermo Protocol, the most important international human rights instrument to combat trafficking, which still applies alongside IHL in time of armed conflicts. ${ }^{10}$ Moreover, this paper analyses whether states have incorporated this crime within their domestic legislations following its ratification. Furthermore, one considers CRSV a mean of war, the crime can be prosecuted under IHL by domestic courts, and, if they are unwilling and unable, by the ICC. ${ }^{11}$ Otherwise, CRSV can be prosecuted by national tribunals under domestic legislations which prohibit such conducts. In light of these remarks, this paper considers four variables.

The first variable verifies whether the country has ratified or accessed the Palermo Protocol. The second one assesses whether trafficking is criminalised and to which extent the domestic legislation matches the international provisions, being A the highest possible standard and $\mathrm{C}$ the lowest or a non-existing provision. Category $\mathrm{A}$ indicates those countries where the crime of trafficking is prohibited, meets the definitional criteria set out by the Palermo Protocol and explicitly includes sex trafficking or trafficking for sexual exploitation. Category B includes those countries where the crime of trafficking is prohibited by law but does not fully meet the definitional criteria and/or does not explicitly include sex trafficking. Finally, category $\mathrm{C}$ encompasses those countries where trafficking is not criminalised.

The third and fourth variables evaluate whether sexual violence is criminalised both a) in war-time and b) in peace-time. As far as the former is concerned, Category A includes all the countries that are party to the ICC and have an adequate implementing legislation covering CRSV. Category B indicates both the countries party to the ICC without adequate implementing legislation or those not party the ICC but with domestic provisions specifically criminalising international crimes including CRSV as acts, while category $\mathrm{C}$ refers to those countries not party to the ICC and without any domestic provisions criminalising CRSV as international crimes. Sexual violence is a broad term that, as the Secretary-General explained, includes a wide range of acts. ${ }^{12}$ This variety, based on Articles 7 and 8 of the Rome Statute, may pose a challenge when looking at the national criminal law framework in time of peace because these acts may constitute different types of domestic crimes, which are often not included under a common label of 'sexual violence', being the latter rather associated with rape. Moreover, cultural, historical, traditional and religious elements may have an influence in the qualification of a specific act as a crime. Sexual violence can be equally perpetrated against women, men, girls or boys. However, the term and the acts that are included are commonly associated with women or with children only, and this approach is often reflected in domestic legislation. On this basis, the analysis of sexual violence-related crimes in time of peace opted for a categorisation into three groups: A, B and C. Category A, which mirrors the definition in the 2018 Report, indicates those countries where sexual violence is criminalised and includes more than simply rape and establishes that both men and women (adult and children) could be victims. Category B indicates those countries where sexual violence is criminalised but the crime includes only rape or is limited to acts against women and children. Finally, category $\mathrm{C}$ indicates those countries without any provision criminalising sexual violence. Table 1 sums up this analysis.

\section{Table 1.}

\footnotetext{
${ }^{9}$ S. Sivakumaran, 'International Humanitarian Law' in International Human Rights Law ed D. Moeckli, S. Shah and S. Sivakumaran (OUP, 2010), 521, at 521.

${ }^{10}$ Ibid.

${ }^{11}$ Arts. $1-17$ of the Rome Statute.

122018 Report, para 2.
} 


\begin{tabular}{|l|l|l|l|l|}
\hline & 1.Palermo & \multicolumn{2}{|l|}{$\begin{array}{l}\text { 2.Crime of } \\
\text { Protocol }\end{array}$} & \multicolumn{2}{|l|}{$\begin{array}{l}\text { 3.Sexual violence } \\
\text { Trafficking }\end{array}$} \\
& & & \multicolumn{2}{l|}{$\begin{array}{l}\text { related crimes } \\
\text { a. }\end{array}$} \\
\hline Afghanistan & YES & A & A & A \\
\hline Central African Republic & YES & A & A & B \\
\hline Colombia & YES & B & A & A \\
\hline Democratic Republic of Congo & YES & C & A & A \\
\hline Iraq & YES & B & C & B \\
\hline Libya & YES & B & C & C \\
\hline Mali & YES & A & A & B \\
\hline Myanmar & YES & A & C & C \\
\hline Somalia & NO & C & C & C \\
\hline South Sudan & NO & B & C & B \\
\hline Sudan & YES & B & C & B \\
\hline Syrian Arab Republic & YES & B & n/a & n/a \\
\hline Yemen & NO & C & C & A \\
\hline
\end{tabular}

\subsubsection{Palermo Protocol}

As Table 1 shows, almost all the countries under analysis ratified or accessed the Palermo Protocol. Mali, Colombia and Libya were among the participating countries to the drafting process and among the first to ratify the Protocol between 2002 and 2004. Other countries, like Sudan and Afghanistan accessed the Protocol only in 2014. On the contrary, South Sudan, Somalia and Yemen are yet to be a party to the treaty and no diplomatic measures are in place at the moment to this end. Nevertheless, this promising picture with 10 out of 13 countries bound by the international treaty is of little importance without adequate domestic implementation framework. For this reason, the next section investigates whether such a domestic implementation actually took place.

\subsubsection{The Crime of Trafficking}

To be able to prosecute someone for having committed sex trafficking, it is necessary to have a crime of trafficking in national legislation. According to Article 3 of the Palermo Protocol, trafficking shall require action (e.g. recruitment, transportation, transfer, or harbouring), means (e.g. by means of the threat or use of force or other forms of coercion, of abduction, of fraud), and purpose (e.g. exploitation). As already clarified above, the analysis of the criminalisation of trafficking made for this article distinguished three categories A, B and C.

${ }^{13}$ Accession (a) and ratification (r) dates as follow: Afghanistan (a) 15 August 2014; CAR (a) 6 October 2006; Colombia (r) 4 August 2004; Iraq (a) 9 February 2009; Libya (r) 24 October 2004; Mali (r) 12 April 2002; Myanmar (a) 30 March 2004; Sudan (a) 2 December 2014; Syrian Arab Republic (r) 8 April 2009.

${ }^{14}$ Afghanistan: Law on the Campaign Against Abduction and Human Trafficking No. 952 (2008); CAR: Article 151, Penal Code; Colombia: Law No. 985 (2005); Iraq: Law No. 28 (2012); Libya: Penal Code; Mali: Law 23 (2012); Myanmar: Chapter I, Anti-trafficking in persons law No. 5 (2005); South Sudan: Article 282, Penal Code; Sudan: Section 7, Chapter III, Combating Human Trafficking Act (2014); Syria: Decree No. 3 (2011).

${ }^{15}$ CAR: Section II (Articles 112-117) and Article 81 Penal Code; Colombia: Law No. 1527 (2008) and Law 1719 (2014) on sexual violence in armed conflicts; DRC: Laws 18 (2006) and 19 (2006) amending the Penal Code; Iraq: Sections 396-398 Penal Code; Mali: Articles 224-227 Penal Code; South Sudan: Chapter XVIII Penal Code; Sudan: Sections 316-319 Penal Code. 
Afghanistan, CAR, Mali and Myanmar are included in category A because they meet the criteria set out in the Palermo Protocol. The relevant provisions can be contained in the penal code, such as for CAR that in its amended 2010 version included a very detailed and international standards-compliant provision on trafficking. ${ }^{16}$ Alternatively, the criminalisation of trafficking can be established by a specific piece of legislation. Mali, for example, approved anti-trafficking legislation in 2012, where the definition of trafficking mirrored that proposed by the Palermo Protocol. ${ }^{17}$

The majority of the countries under analysis, 6 , falls within category $\mathrm{B}$, according to which the crime of trafficking is prohibited by law but does not fully meet the definitional criteria. For instance, Colombian 2005 anti-trafficking law lacks the element of the means in its definition of trafficking and, therefore, fails to comply with international standards. ${ }^{18} \mathrm{On}$ the contrary, Libya's criminal code criminalises trafficking but no reference can be found to both the elements constituting trafficking and the specific instance of sex trafficking. ${ }^{19}$

Finally, DRC, Somalia and Yemen have not criminalised trafficking falling within category C. Nevertheless, although no reference to trafficking is made, Yemen's penal code criminalises slavery. ${ }^{20}$ Similarly, Somalia's provisional draft for the new constitution includes a provision prohibiting trafficking but this is not criminalised and thus, not prosecutable. ${ }^{21}$

\subsubsection{Sexual Violence and Related Crimes}

Considering the focus of this research, the analysis of the domestic framework on trafficking goes hand in hand with that on CRSV. As previously mentioned, when addressing the existing legal framework criminalising CRSV, it is possible to look at the national implementing legislation of the ICC Statute and, in particular, of Articles 7 and 8 of the Rome Statute, respectively, on crimes against humanity and war crimes. For those countries that are not party to the ICC, the analysis focuses on whether their national criminal framework nevertheless include international crimes such as war crimes and crimes against humanity.

Among the 13 countries under analysis only 5 of them are party to the ICC: Afghanistan, Colombia, CAR, DRC and Mali and all of them meet the standard to be labelled as A. Already in 2001, Mali amended its Criminal Code as to include all the international crimes as later established by the Rome Statute. ${ }^{22}$ CAR enacted two important laws in 2010 and 2015 amending the criminal code and criminal procedure code. ${ }^{23}$ Similarly, DRC approved in 2015 three detailed and comprehensive laws amending the criminal code, the criminal military code and the criminal procedure code. ${ }^{24}$ On the same page, Afghanistan new 2017 penal code fully implements the Rome Statute provisions. ${ }^{25}$ Colombia, on the other hand, already had domestic legislation criminalising CRSV as an international crime well before

\footnotetext{
${ }^{16}$ CAR, Penal Code, Law No. 10.001 (2010.). See also Afghanistan, Law 1260 (2017) amending the Penal Code.

${ }^{17}$ Mali, Law No.23 (2012). See also Myanmar, Anti-trafficking in persons law No. 5(2005).

${ }^{18}$ Colombia, Law No.985 (2005).

${ }^{19}$ US Department of State, Office to Monitor and Combat Trafficking in Persons, Trafficking in Persons Report 2018: Libya country narrative.

${ }^{20}$ Yemen, Penal Code.

${ }^{21}$ Provisional constitutional draft text available at http://hrlibrary.umn.edu/research/SomaliaConstitution2012.pdf.

${ }^{22}$ Mali, Law 01.079 (2001) amending the Criminal Code.

${ }^{23}$ CAR: Law N.10.002 (2010) amending the criminal and criminal procedure code; Law N.15.003 (2015) bringing the creation, organisation and functioning of the Special criminal Court.

${ }^{24}$ DRC, Law modifying law N.024.2002 of 18 November 2002 amending the criminal military code (2015); Law modifying and complementing the act of 30 January 1940 amending the criminal code (2015); Law modifying and complementing the act of 6 August 1959 amending the criminal procedure code (2015). ${ }^{25}$ Afghanistan, Law 1260 (2017) amending the Penal Code.
} 
becoming a party to the ICC and continued to improve its national legislation afterward, including a specific piece of legislation on sexual violence in armed conflict approved in 2014. While none of the countries under analysis fit within category B (since there are no states without adequate implementing legislation which criminalise CRSV anyway), 8 countries, which are not party to the ICC, fit within category $\mathrm{C}$ since they have no legislation criminalising CRSV.

As far as the legislation on sexual violence related crimes in time of peace is concerned, only 3 of the 13 countries under analysis (Afghanistan, Colombia and the DRC) criminalise sexual violence falling within Category A. The above-mentioned 2017 amendments to the Afghani Penal Code significantly increase the protection given to victims of sexual violence, including under this umbrella terms a wide range of unlawful acts both against men and women. ${ }^{26}$ In addition to its $2008 \mathrm{Law}$ on crimes against women, ${ }^{27}$ Colombia approved in 2014 a specific law on sexual violence in armed conflict where the term victim includes men, women, girls and boys and the criminalised acts are complying with the list proposed by the SG. ${ }^{28}$ Moreover, Article 6 specifically refers to sex-trafficking in armed conflict, extending the meaning of 'sexual exploitation' to any act of exploitation of a sexual character including servile or forced marriage, sexual servitude, sexual tourism and so on. ${ }^{29}$ Similarly, in DRC, the Penal Code, as amended in 2006, criminalises a wide range of sexual violence-related crimes against both men and women. ${ }^{30}$

Five countries fall within category B indicating that in CAR, Iraq, Mali, South Sudan and Sudan sexual violence is criminalised but the crime includes only rape or is limited to acts against women and children. In Mali and Iraq, only rape and sexual assaults are criminalised, although extended as including both men and women as victims. ${ }^{31}$ On the contrary, in CAR, South Sudan and Sudan the range of sexual-related acts that are criminalised is wider but only when committed against women and children. ${ }^{32}$

Finally, no mention of this in the penal code can be found in Myanmar, Somalia and Yemen. Yet, in Libya, the crime of rape exists but is configured as a crime against the honour of the family of the woman rather than against her integrity and dignity and, as such, it has been deliberately labelled by as inexistent. ${ }^{33}$ All these countries fall under category $\mathrm{C}$.

A final note on Syria. Syria was not included in this analysis for the impossibility of finding a translated version from Arabic of the penal code and accessories pieces of legislation on the matter.

In conclusion, the domestic framework on trafficking and sexual violence of the 13 countries under scrutiny appears only partially adequate to bring the perpetrators of these crimes to justice. Some countries have sufficient regulation and criminalisation of trafficking or sexual violence but only Afghanistan with its new penal code reached a satisfactory level in both. Considering that the two criminal conducts go hand in hand in the context of CRSV and trafficking, this shows the limits of national legislation to adequately understand the nexus between the two crimes and effectively criminalise sexual violence and sex trafficking. Nevertheless, the legislation analysis highlights some positive developments and efforts made

\footnotetext{
${ }^{26}$ Afghanistan, Law 1260 (2017) amending the Penal Code, section 8, Chapter 1.

${ }^{27}$ Colombia, Law No. 1527 (2008).

${ }^{28}$ Colombia, Law No. 1719 (2014).

${ }^{29}$ Ibid., Article 6.

${ }^{30}$ DRC, Laws 18 (2006) and 19 (2006) amending the Penal Code.

${ }^{31}$ Iraq, Penal Code, Articles 396-398; Mali, Penal Code, Articles 224-227.

32 CAR: Penal Code, Section II Articles 81, 112-117; South Sudan: Penal Code, Chapter XVIII; Sudan: Penal Code, Sections 316-319.

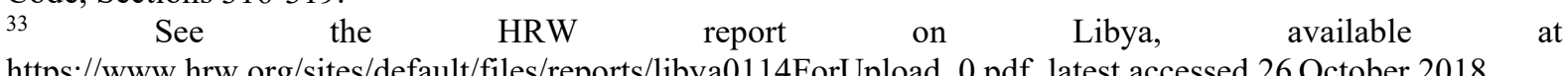
https://www.hrw.org/sites/default/files/reports/libya0114ForUpload_0.pdf, latest accessed 26 October 2018.
} 
towards a more robust framework to address the multifaceted nature of CRSV and trafficking, in compliance with the international standards. This is the case of, for instance, Colombia, Mali or CAR that are very close to have a suitable criminal framework. On the other hand, countries like Yemen or Somalia, and Libya and Myanmar as well to a lesser extent, seem to be very far from this goal. Yet, the challenge of improving the legal framework goes hand in hand with that of ensuring its enforcement and application. One without the other may result in being completely useless in addressing CRSV and trafficking. The following section explores some of these challenges.

\subsection{Enforcement Challenges}

Many enforcement aspects may significantly limit the effectiveness of domestic criminal law during an armed conflict. They concern all the stages from the acknowledgment of the crime, to investigation, prosecution and enforcement of the judgment.

To start with, the existence of a conflict may limit the acquisition of information from the affected regions and complicate the discovery or acknowledgment of the crimes committed. Normal channels of communication and government's peripheral government networks are often suspended or altered. Moreover, government officials are sometimes not able to reach certain areas affected by the conflict, as it happened in Darfur and Syria, with consequential underreporting of crimes. ${ }^{34}$

Furthermore, law requires enforcement agencies with powers to appropriately address the challenges deriving from the fight against the crime of trafficking. ${ }^{35}$ More specifically, each state should be equipped with specialist and centralised anti-trafficking units, which should enforce the law. ${ }^{36}$ They are a fundamental piece for ensuring the effectiveness of a domestic anti-trafficking criminal law system, as they are in charge of both conducting investigations and enforcing the court's judgments. Out of the 13 countries, only 5 of them (Afghanistan, Colombia, Myanmar, Somalia and Sudan) have a specialised law enforcement unit or a subunit or team within the law enforcement structure that has specialised mandate to conduct investigations into trafficking. ${ }^{37}$ From this perspective, it is interesting to note that trafficking in Somalia has not an exact definition since it is only prohibited in the Draft Constitution, while specific legislations exist for the other four countries. ${ }^{38}$ However, there is no evidence that any of these enforcement units are fully funded or have sufficient budget to carry out the duties for which they were created. ${ }^{39}$ Therefore, these trafficking units might only be empty shells with no actual functions. From this perspective, it should be recalled that all the countries under analysis are currently experiencing international or national conflicts. This has been affecting their response to crimes because many countries lack basic infrastructures. ${ }^{40}$ In Afghanistan, for instance, four specific anti-trafficking units have been recently established: the AntiTrafficking-in-Persons (TIP) Unit, the Afghanistan Border Police (ABP) Unit, the trafficking units of the National Directorate for Security (NDS) and those of the National Central Bureau (NCB) of the INTERPOL. Nevertheless, a recent study reveals that none of them benefit from

\footnotetext{
${ }^{34}$ Conflict-related Sexual Violence: Report of the Secretary General S/20014/181, 13 March 2014, $15,17$.

${ }^{35}$ A. Gallagher \& P. Holmes, 'Developing an Effective Criminal Justice Response to Human Trafficking: Lessons from the Front Line', International Criminal Justice Review 18 (2008): 323.

${ }^{36}$ Ibid., 324.

${ }^{37}$ Global Slavery Index 2018, Government response data, available at https://www.globalslaveryindex.org, latest accessed 26 October 2018; W. M. Kandiwal, A Mapping Study: Institutional Mechanisms to Tackle Trafficking in Persons in Afghanistan, AREU Policy Note, March 2018.

${ }^{38}$ See footnote 21.

${ }^{39}$ Ibid.

${ }^{40}$ F. Ní Aoláin, On the frontlines: gender, war, and the post-conflict process (OUP, 2012).
} 
the necessary funding to carry out their functions, thus significantly limiting their possibility of action. ${ }^{41}$ Similarly, in Somalia, the Somali Police Force (SPF) should have a 40-officer Counter-Trafficking and Organized Crime Unit, but apparently this unit has never received counter-trafficking training and entered into force. ${ }^{42}$

Moreover, it must be recalled that, in order to start an investigation and bring the responsible to justice, the cooperation of victims and witnesses is required. However, victims are generally reluctant to take part in the proceedings and they might suffer from several mental health issues, such as anxiety, depression and post-traumatic stress disorder. ${ }^{43}$ Thus, speaking about their experiences might deepen their trauma, especially if they need to testify about intimate details before the judges in unfamiliar settings. ${ }^{44}$ To this, it must be added that victims of sexual crimes are often stigmatised for having being raped, having contracted HIV/AIDS, being unmarriable, having children as a result of rape and, consequently, isolated by their families and communities. ${ }^{45}$ Thus, they might not come forward for fear of retaliation. To address these issues, states should quickly identify CRSV and trafficking victims and provide them with appropriate protective and supportive measures. However, from the data available, it seems that only Colombia and Mali have protective measures which can be applied inside the courtroom to safeguard witnesses' identity and support them in the difficult phases of the testimony. ${ }^{46}$ Conversely, none of the 13 countries have protection mechanism for victims and witnesses outside the courtroom.

This complex pattern is made even more complicated by the very same nature of the crimes, which are not ordinary crimes. Trafficking, for instance, has a transnational dimension. Traffickers exploit this situation to their advantage. Therefore, national institutions which are already weakened by the war context, might be unable to follow both the perpetrators and the victims to a different state. Studies have shown that transnational organised crime groups work in small groups to achieve their criminal purposes since bigger and centralised structures are more easily targeted and caught by law enforcement measures. ${ }^{47}$ For this reason, an active coordination and cooperation among governments of different countries is necessary to curb these crimes.

\subsection{Challenges and Perspectives: The Limits of National Criminal Law for Addressing CRSV and trafficking and the International Scope of These Crimes}

Although national states should be primarily responsible for prosecuting crimes committed within its jurisdiction and bring prosecutors to justice, the previous analysis showed that they

\footnotetext{
${ }^{41}$ Kandiwal: 4.

${ }^{42}$ US Department of State, Office to Monitor and Combat Trafficking in Persons, Trafficking in Persons Report 2017: Somalia country narrative.

${ }^{43}$ De Brouwer, 'The Importance of Understanding Sexual Violence in Conflict for Investigation and Prosecution Purposes': 113. See also P. Kuwer et al, 'Long Term Effects of Conflict-Related Sexual Violence Compared with Non-Sexual War Trauma in Female World War II Survivors: A matched Pairs Study', Archives of Sexual Behaviour 43(6) (2014); E. Josse, 'They Came with Two Guns: The Consequences of Sexual Violence for the Mental Health of Women in Armed Conflicts', International Revue of the Red Cross 92(2010): 183.

${ }^{44}$ A. de Brouwer, Supranational Criminal Prosecution of Sexual Violence: The ICC and the Practice of the ICTY and the ICTR (Antwerp-Oxford: Intersentia, 2015): 231-82.

${ }^{45}$ De Brouwer, Supranational Criminal Prosecution of Sexual Violence: 234; S. K. H. Chu et al., Survivors of Sexual Violence in Conflict: Challenges in Prevention and International Criminal Prosecution in Victimological Approaches to International Crimes: Africa, ed Rianne Letschert et al. (Antwerp-Oxford: Intersentia, 2011): 53539.

${ }^{46}$ Global Slavery Index 2018, Government response data.

47 S. L. Mallory, Understanding Organized Crime (Criminal Justice Illuminated), (Sudbury, Jones \& Bartlett Publishers, 2007).
} 
may not be fully equipped to do so, especially in situations of conflicts. The legal framework in the 13 countries identified by the SG Report proved to be overall inadequate to prosecute CRSV and trafficking and to understand the nexus between these two crimes. Although some countries, such as Colombia and Mali, have a more advanced framework than others, their criminal law machinery remain inappropriate to break the circle of impunity that link them. Moreover, enforcement obstacles imposed by the situation of conflict, the lack of resources and training and the sensitivity of the crimes at stake make the domestic criminal law response to CRSV and trafficking even more limited.

As a consequence, this article suggests that national efforts should be complemented at the international level. While CRSV are international crimes recognised by the Rome Statute, the nature of trafficking is still debatable. The Palermo Protocol endorses a traditional approach, according to which trafficking is a transnational crime. This is clear from the fact that the Protocol is designed to promote the cooperation between the states to combat trafficking. ${ }^{48}$ However, the idea that trafficking should be treated as an international crime is well promoted by many scholars. For instance, Tavakoli believes that, if the international community considers trafficking as a transnational crime, it neglects the essence of the crime, which offends fundamental humanitarian values and conscience of humankind. ${ }^{49}$ This view is also shared by Aston and Chuang. ${ }^{50}$ Quoting Robert Cryer, for instance, Aston believes that trafficking should be upgraded from a transnational crime to an international one for principled and practical reasons, such as beliefs and the values they are in conflict with are sufficiently important to the international community and that international prosecution is an effective way of dealing with them. ${ }^{51}$ With this in mind, this article discusses the role of the ICC, the first permanent international criminal institution, in prosecuting the allegedly responsible for CRSV and trafficking.

\section{CRSV and Trafficking as International Crimes}

To date, the Rome Statute, the governing multilateral treaty of the ICC, has been signed by 123 States. ${ }^{52}$ However, despite its potential global reach, the ICC can only prosecute the crimes that have been committed within its jurisdiction. ${ }^{53}$ Thus, the first obstacle to face when prosecuting those responsible for CRSV and trafficking is the issue of jurisdiction, which is analysed in the next section.

\subsection{Jurisdiction}

As clarified in the previous section, the ICC can only prosecute those crimes which are carried out in the states that have accepted its jurisdiction. However, among the 13 countries indicated

${ }^{48}$ Gallagher \& Holmes, 318.

${ }^{49}$ N. Tavakoli, 'A Crime that Off ends the Conscience of Humanity:A Proposal to Reclassify Traffi cking in Women as an International Crime' International Criminal Law Review 9 (2009), 78.

${ }^{50}$ J. N. Aston, Trafficking of Women and Children: Article 7 of the Rome Statute (OUP, 2016); J. Chuang, 'Redirecting the Debate over Trafficking in Women: Definitions, Paradigms, and Contexts', Harvard Human Rights Journal 11 (1998): 65.

${ }^{51}$ R.Cryer et al., An Introduction to International Criminal Law and Procedure (CUP, 2007), 282.

52 ICC, 'The States Parties to the Rome Statute', https://asp.icccpi.int/en_menus/asp/states\%20parties/pages/the $\% 20$ states $\% 20$ parties $\% 20$ to $\% 20$ the $\% 20$ rome $\% 20$ statute.aspx, 1 September 2018, latest accessed 26 October 2018.

${ }_{53}$ Art. 12(1) of the Rome Statute. 
in the 2018 Report, only 5 states are parties to the Rome Statute. ${ }^{54}$ These states are Afghanistan, CAR, Colombia, DRC and Mali. The lack of ratification of the Rome Statute by the other 8 countries constitutes a difficult but not impossible obstacle for the prosecution of CRSV and trafficking by the ICC. Indeed, it can be nuanced in two circumstances.

First, according to Article 13 of the Rome Statute, the jurisdiction of the ICC can be triggered by a State Party, the ICC Prosecutor and the Security Council acting under Chapter VII of the Charter of the United Nations in order to maintaining international peace and security. In the latter case, it is not necessary that the state is party to the Rome Statute because the legal obligation for the ICC derives from the very same UN Security resolutions, which are binding upon United Nations Member States in accordance with Article 25 of the UN Charter. ${ }^{55}$

The legal provision of the Rome Statute dealing with the referral by the Security Council has been one of the most scrutinised provisions of the entire Rome Statute. ${ }^{56}$ Because of this provision, the ICC has been accused of adopting a selective justice system and of letting an obligation never accepted by certain states enter from the backdoor ${ }^{57}$ Despite this criticism, the ICC has used this referral mechanism twice. The first time, the situation in Darfur was at the centre of the Resolution 1593 (2005), which authorised the ICC to exercise its jurisdiction over crimes listed in the Rome Statute committed on the territory of Darfur or by its nationals from 1 July 2002 onwards. ${ }^{58}$ The second time, the ICC referred the situation in Libya so that the ICC could exercise its jurisdiction over crimes committed on the territory of Libya or by its nationals from 15 February 2011 onwards. ${ }^{59}$ In Darfur, some Sudanese Government officials, Militia/Janjaweed leaders, and leaders of the Resistance Front were charged only with rape as far as CRSV is concerned. ${ }^{60}$ No other charges for sexual violence crimes were issued. However, none of these people were convicted since most of the indicted are still at large. In Libya, the majority of charges involved crimes against humanity, such as murder and persecution although an arrest warrant for rape was issued towards Al-Tuhamy Mohamed Khaled. ${ }^{61}$ Furthermore, although no formal charges have been issued in relation to trafficking

\footnotetext{
${ }^{54}$ Ibid.

55 A. S. Galand, 'Security Council Referrals to the International Criminal Court as Quasi-Legislative Acts', Max Planck Yearbook of United Nations Law, 19 (2015): 143.

${ }^{56}$ V. O. Ayeni \& M. A. Olong, 'Opportunities and Challenges to the UN Security Council Referral Under the Rome Statute of the International Criminal Court', African Journal of International and Comparative Law 25 (2017): 239; A. Hehir \& A. Lang, 'The Impact of the Security Council on the Efficacy of the International Criminal Court and the Responsibility to Protect', Criminal Law Forum, 26 (2016): 153; A. S. Knottneru, 'The Security Council and the International Criminal Court: the Unsolved Puzzle of Article 16, Netherlands International Law Review, 61, (2014): 195.

${ }^{57}$ C.C. Jalloh, 'The African Union, the Security Council and the International Criminal Court' in C.C. Jalloh \& I. Bantekas (eds.) The International Criminal Court and Africa (OUP, 2017); T. Lattmann, 'Situtations Referred to the International Criminal Court by the United Nations Security Council - Ad Hoc Tribunalisation of the Court and its Dangers', Pecs Journal of International and European Law, 2 (2016): 68: A. Zimmermann, 'Two Steps forward, one step backwards?: Security Council Resolution 1593 (2005) and the Council's Power to refer Situations to the International Criminal Court' in Common Values in International Law: Essays in Honour of Christian Tomuschat ed P. Dupuy et al. (Engel, 2006), 681.

${ }^{58}$ UN Security Council, Security Council resolution 1593 (2005) [on Violations of International Humanitarian Law and Human Rights Law in Darfur, Sudan], 31 March 2005, S/RES/1593 (2005).

59 UN Security Council, Security Council resolution 1970 (2011) [on establishment of a Security Council Committee to monitor implementation of the arms embargo against the Libyan Arab Jamahiriya], 26 February 2011, S/RES/1970 (2011).

${ }^{60}$ Prosecutor v Al Bashir, 'Warrant of Arrest for Omar Hassan Ahmad Al Bashir', ICC-02/05-01/09-1, Pre-Trial Chamber I, 4 March 2009; Prosecutor v Harun and Kushayb, 'Warrant of Arrest for Ahmad Harun', ICC-02/0501/07-2, Pre-Trial Chamber I, 27 April 2007; Prosecutor v Hussain, 'Warrant of Arrest for Abdel Raheem Muhammad Hussain', ICC-02/05-01/12-2, Pre-Trial Chamber I, 1 March 2012.

${ }^{61}$ For Libya see The Prosecutor v. Al-Tuhamy Mohamed Kaled, 'Warrant of Arrest for Al-Tuhamy Mohamed Khaled with under seal and ex parte Annex', Pre-Trial Chamber I, ICC-01/11-01-13-1, 24 April 2017, 7-9.
} 
in Libya, in its Report to the Security Council, Bensouda clarified that the OTP launched several initiatives to disseminate and the profiles of high-priority individuals who are allegedly involved in trafficking of human beings. ${ }^{62}$ Although the ICC has caught the nexus between these two types of crimes in certain instance, these episodes show that there is still a lot of work to be done since both countries are included in the 2018 Report among those where a strong link between CRSV and trafficking has been registered. Indeed, in avoiding to prosecute and convict those allegedly responsible for CRSV, the ICC allowed trafficking to flourish.

In addition to this, it must be noted that the issue of jurisdiction must take into consideration the transnational nature of the involved crimes. A good example of this can be found in the referral made by Bangladesh for the alleged deportations of Rohingya Muslims from Myanmar to Bangladesh. While the ICC has no jurisdiction over Myanmar, Bangladesh is a state party to the Rome Statute. Pre-Trial I ruled that the ICC may exercise its jurisdiction over the alleged deportation of the Rohingya people from Myanmar to Bangladesh since one of the elements of the crime (conduct) is committed on the territory of a State Party and, thus, within the ICC's jurisdiction. ${ }^{63}$ This referral has the potential to open new ways to prosecute crimes of inherently transboundary nature. Despite this encouraging perspective, it should be noted that the OTP did not attempt to prosecute those responsible for CRSV and trafficking of Rohingya Muslims. The 2018 Report clarified that when the UN Special Representative visited camps and settlements in Cox's Bazar (Bangladesh) in November 2017, she heard testimonies of 'almost every woman and girl of patterns of rape, gang rape, forced nudity and abduction for the purpose of sexual slavery during military campaigns'. ${ }^{64}$ Thus, although it could have been easy to find evidentiary sources to prove that those responsible for CRSV had also trafficked the victims for the purpose of sexual exploitation, the Prosecutor asked the Pre-Trial Division to open an investigation only for the crime of deportation of 670,000 Rohingya, lawfully present in Myanmar, who were intentionally deported across the international border into Bangladesh on the basis of Article 7(1)(d) of the Rome Statute. ${ }^{65}$

Against this background, it must be noted that while CRSV such as rape, sexual assault, enforced prostitution, forced pregnancy, and enforced sterilisation are now considered international crimes and recognised in Articles 7(1)(g), 8(2)(b)(xxii) and 8(2)(b)(e)(vi) of the Rome Statute, trafficking is not contained in any of these categories. This represents a big obstacle to the prosecution of those responsible for trafficking especially considering that sexual crimes in a conflict-related context operate in a vicious cycle.

The absence of the crime for 'trafficking of persons' within the Rome Statute limits the power of the ICC to prosecute the allegedly responsible for trafficking. However, the ICC tried to include the trafficking within the crimes of slavery and enslavement, which are listed among crime against humanity. This is clear from both the Rome Statute and the Elements of Crimes. Indeed, Article 7(2)(c) of the Rome Statute states that enslavement 'includes the exercise of such power in the course of trafficking in persons, in particular women and children'. Similarly, the Elements of Crime clarifies that the conducts of purchasing, selling, lending or bartering such a person or persons, or by imposing on them a similar deprivation of liberty under the crime against humanity of enslavement (Articles 7(1)(c)), crime against humanity of sexual slavery (Article 7(1)(g)-2), war crime of sexual slavery (Article 8(2)(b)(xxii)-2) and war crime

\footnotetext{
62 OTP, Fifteen Report of the Prosecutor of the International Criminal Court to the United Nations Security Council Pursuant to UNSCR 1970 (2011), 9 May 2018, 33.

${ }^{63}$ Request under Regulation 46(3) of the Regulations of the Court, 'Decision on the "Prosecution's Request for a Ruling on Jurisdiction under Article 19(3) of the Statute”, ICC-RoC46(3)-01/08-37, Pre-Trial Chamber I, 6 September 2018.

${ }^{64} 2018$ Report, 55.

${ }^{65}$ ICC, Prosecution's Request for a Ruling on Jurisdiction under Article 19(3) of the Statute, President of the Trial Division, ICC-RoC46(3)-01/18-1, 9 April 2018.
} 
of sexual slavery (Article 8(2)(e)(vi)-2) include trafficking, in particular women and children. ${ }^{66}$ Regardless of whether the relevant conduct falls within the category of crimes against humanity or war crimes, the two crimes of sexual slavery and enslavement seem to be two umbrella terms which include trafficking.

Under the Rome Statute, the two crimes of slavery and enslavement are synonymous since they are defined using the same terminology, i.e. '[t]he perpetrator exercised any or all of the powers attaching to the right of ownership over one or more persons, such as by purchasing, selling, lending or bartering such a person or persons, or by imposing on them a similar deprivation of liberty'. ${ }^{67}$ Despite this, Sillers tried to distinguish the two terms investigating their relationship with the crime of trafficking. Specifically, she believes that, in light of the international criminal jurisprudence, these two terms should not be considered as synonyms because international jurisprudence supports the view that a material link exists between enslavement and trafficking. ${ }^{68}$ Unfortunately, the premises on which Sillers's view is based are fallacious since she uses the case-law of other international criminal tribunals to clarify the meaning of the terms 'slavery' and 'enslavement' in the Rome Statute. However, this case-law is not contained among the sources of law applicable by the ICC judges under Article 21 of the Rome Statute. Conversely, it includes the Rome Statute, Elements of Crimes and Rules of Procedure and Evidence, which support the view that these two terms should be considered as synonyms. In absence of any jurisprudence which clarifies whether the two terms of slavery and enslavement are synonyms, it is not possible to agree with Sillers's interpretation. Furthermore, a closer interpretation of the Article 21(3), which reads that the interpretation of law must be consistent with internationally recognised human rights, fosters the idea that the term 'trafficking' should be interpreted in light to the Palermo Protocol and, thus, considered as a separated crime. Thus, in order to understand whether sexual slavery (and its synonymous term of enslavement) can be used to provide legal coverage to the crime of trafficking for the purpose of sexual exploitation, it is necessary to understand the meaning of 'sexual slavery'.

\subsection{Sexual Slavery as Trafficking for the Purpose of Sexual Exploitation}

Trafficking for the purpose of sexual exploitation and sexual slavery are not necessarily synonymous, although the term 'sexual' indicates the limitations of someone's autonomy and power to decide about their own sexual activity. ${ }^{69}$ As already mentioned in Section 1, the key elements of trafficking are the elements of action, means and purpose. As far as 'sexual slavery' is concerned, Article 7(2)(c) provides a definition of 'enslavement' as the 'exercise of any or all the powers attaching to the right of ownership over a person and includes the exercise of such power in the course of trafficking, in particular women and children'. The key element of this definition, which entails the right of ownership, is akin to the description of the crime of 'slavery' under the 1926 Slavery Convention. ${ }^{70}$ In addition to this, Article 7(1)(c) of Elements of Crimes of the Rome Statute clarifies that 'the perpetrator exercised any or all of the powers attaching to the right of ownership over one or more persons, such as by purchasing, selling, lending or bartering such a person or persons, or by imposing on them a similar deprivation of

\footnotetext{
${ }^{66}$ ICC, Element of Crimes, footnotes 11, 18, 53 and 66.

${ }^{67}$ Articles 7(1)(c), Article 7(1)(g)-2), Article 8(2)(b)(xxii)-2) and Article 8(2)(e)(vi)-2 of the Elements of Crimes.

${ }^{68}$ N. Sillers, 'Modern Slavery: Does International Law Distinguish between Slavery, Enslavement and Trafficking', Journal of International Criminal Justice 14 (2016), 406, 407 and 426.

69 C. K. Hall, 'Article 7' in Rome Statute of the International Criminal Court: a Commentary ed O. Triffterer (Munich: G.H. Beck, Hart, Nomos, 2015), 144, at 212.

${ }^{70}$ League of Nations. 1926. Slavery convention, Geneva, September 25th 1926, 60 LNTS 253.
} 
liberty'. This definition contains some elements which are similar to the definition of trafficking. As far as the action is concerned, while trafficking requires 'the recruitment, transportation, transfer, harbouring or receipt of persons', slavery focuses on actions like 'purchasing, selling, lending or bartering such a person or persons, or by imposing on them a similar deprivation of liberty'. From this perspective, the conducts seem to be quite different. However, since both lists are not exhaustive, it is not possible to exclude the overlap of some conducts. Furthermore, the Rome Statute does not explicitly include the element of 'means', since it only refers to the 'the right of ownership over one or more persons'. However, an implicit reference to the elements of 'means', according to which slavery must be the result of coercion, threat or force, as requested by the Palermo Protocol, seems to be supported by Trial Chamber II in Katanga.$^{71}$ Here, Trial Chamber II clarified that 'the powers attaching to right of ownership must be construed as the use, enjoyment and disposal of a person who is regarded as property, by placing him or her in a situation of dependence which entails his or her deprivation of any form of autonomy'. ${ }^{72}$ If the element of lack of autonomy is interpreted to imply the use of coercion or force, it can be concluded that the definition of slavery might include the element of means. Furthermore, the third element, the purpose of sexual exploitation, required by the Palermo Protocol, seems to be present in the definition of 'sexual slavery'. Indeed, as clarified by Article $7(1)(\mathrm{g})-2$ of the Elements of Crime, 'the perpetrator caused such person or persons to engage in one or more acts of a sexual nature'.

Finally, it should be noted that Article 7(1)(g)-2 of the Elements of Crime indicates that other three elements are necessary to qualify the crime of sexual slavery as a crime against humanity. It says that ' $[t]$ he conduct was committed as part of a widespread or systematic attack directed against a civilian population. The perpetrator knew that the conduct was part of or intended the conduct to be part of a widespread or systematic attack directed against a civilian population'. The elements of widespread or systematic attack, the fact that this must be directed against a civilian population and the mens rea, i.e. knowledge of the perpetrator, is not required by the definition of trafficking, as defined by the Palermo Protocol. While Aston believes that these elements are always present in the crime of trafficking because they are often directed towards a specific group of people and that the perpetrator is aware of the act of the organized crime supporting the crime against humanity, this article suggests that these elements must be demonstrated on a case-by-case basis. ${ }^{73}$

Also, the ICC's practice shows that the link between these two types of crimes have been neglected by the OTP and Pre-Trial Chambers. The crime of sexual slavery has been charged three times, in the cases of Katanga and Ngudjolo, Ntaganda and Kony. ${ }^{74}$ The first two cases are based in the DRC, while the investigation into Kony's conducts are located in Uganda. Although the DRC is indicated by the Secretary-General in its 2018 Report as one the countries where SCSV and trafficking are deeply linked but the ICC has only referred to sexual slavery in the Ntaganda and Katanga, where the accused were charged (but not convicted) with the crime against humanity of sexual slavery for the actions committed by their troops in the

\footnotetext{
${ }^{71}$ Prosecutor v. Katanga, 'Judgement Pursuant Article 74 of the Statute', Trial Chamber II, ICC-01/04-01/073436-tENG, 20 April 2015, 975. For a different view on this point, see Hall, A, 214.

72 Ibid.

73 Aston, 165.

${ }^{74}$ Prosecutor v. Ntaganda, Decision Pursuant to Article 61(7)(a) and (b) of the Rome Statute on the Charges of the Prosecutor Against Bosco Ntaganda, Pre-Trial Chamber II, ICC-01/04-02/06-309, 9 June 2014, 36; Prosecutor v. Katanga and Ngudjolo, Decision on the Confirmation of Charges, Pre-Trial Chamber I, ICC-01/0401/07-717, 30 September 2008; Prosecutor v. Kony et al, 'Warrant of Arrest for Joseph Kony ' Issued on 8 July 2005 as Amended on 27 September 2005, Pre-Trial Chamber II, ICC-02/04-01/05-53, 27 September 2005.
} 
Ituri Province in the DRC. ${ }^{75}$ Conversely, no attention has been given to trafficking. Furthermore, the difficulties to charge individuals for trafficking is even clearer in the Arrest Warrant for Al-Bashir because despite the fact that the 2018 Report included Darfur among those regions where a strong link between CRSV and trafficking exists, the Arrest Warrant only mentions the crime of rape. ${ }^{76}$ From this analysis, it is clear that the ICC has completely overlooked the crime of trafficking for the purpose of sexual exploitation. This can be explained by the fact that this crime is not explicitly mentioned in the Rome Statute and, thus, the OTP would have no reasons to collect evidence on a crime, which is not within the ICC's jurisdiction.

Rebus sic stantibus, the scope of the crime of sexual slavery could be expanded to include the crime of trafficking for the purpose of sexual exploitation, in line with the Rome Statute and the Elements of Crimes. Although the two crimes are distinct, this would be possible using an evolutive interpretation of the term 'sexual slavery'. Indeed, it must be noted that at the time of the adoption of the Rome Statute, the Protocol Palermo with the definition of trafficking, did not exist yet. However, in absence of any case-law of the ICC on this issue, it is difficult to predict whether the judges will use this broad interpretation and whether, for instance, they would choose to differentiate the crime of 'slavery' from the crime of 'enslavement'. However, this solution would not be in line with internationally recognised human rights under Article 21(3) of the Rome Statute and, more specifically, with the Palermo Protocol which defines the crime of trafficking as a distinct form of crime, separated by the crime of slavery. For this reason, this article suggests a modification of the Rome Statute in order to encompass, among the crimes against humanity, the crime of trafficking, and, more specifically, the crime of trafficking for the purpose of sexual exploitation. This solution has the advantage to safeguard nexus between CRSV and trafficking and stresses that only moving trafficking from the shade of CRSV, the ICC would give the trafficking crimes the attention they deserve.

\section{Conclusions}

CRSV and trafficking are strictly related, especially in the context of armed conflict since they both spring from the same root of criminality and feed each other. Thus, they should be tackled together because only by breaking the chain of impunity for one it is really possible to ensure justice for the other.

States should be the main actors in fighting against these heinous phenomena although they are often those involved first-hand in these acts. The analysis of domestic legislation reveals a very diversified picture in the 13 countries currently in conflict identified by the Secretary-General with an overall poor performance. Some of them, such as Colombia, Mali and CAR are making important steps toward complying with international standards by adequately criminalise trafficking in an effective and comprehensive way and have ratified to the Rome Statute. Other countries remain well behind, far from meeting any minimum standards and without apparent interest in acceding the Palermo Protocol and the Rome Statute. Similarly, only few states, such as Afghanistan, CAR, Colombia, DRC and Mali.

However, any legal framework can be effective only if properly enforced. In situation of armed conflict, this enforcement is made even harder. In particular, this article identified the lack of specific anti-trafficking law enforcement units or normal law-enforcement units trained

\footnotetext{
${ }^{75}$ Prosecutor $v$ Ntaganda, ICC-01/04-02/06-309, 36. Prosecutor $v$ Katanga and Ngudjolo, Decision on the Confirmation of Charges, Pre-Trial Chamber I, ICC-01/04-01/07-717, 30 September 2008.

${ }^{76}$ Prosecutor v. Al-Bashir, Second Decision on the Prosecutor's Application for a Warrant of Arrest, ICC-02/0501/09, 12 July 2010, 106.
} 
on how to deal with trafficking as one big obstacle for adequate investigations and judgments. Especially in the context of conflicts, the lack of staff, resources and training to these units make it sometimes impossible for governmental officials to acknowledge the existence of CRSV or trafficking, to conduct a proper investigation and, to ultimately stop the crime and bring justice. Similarly, the lack of services for victims of both crimes prevent the latter from participating in the investigations and proceedings, limiting their effectiveness. Considering the sensitivity of the issue, the transboundary nature of the crime and role that sometimes is played by cultural, religious and societal concerns, it is fundamental to have dedicated services to apply in these circumstances and adequate staff to enforce it. The variable of conflict further complicates this picture, making the domestic criminal framework unable to practically address CRSV and trafficking.

The international criminal framework could offer an alternative for prosecuting CRSV and trafficking. However, this article showed that, out of the 13 countries where a deep link between these two types of crimes exist, only 5 are parties to the Rome Statute. This limits the possibility of international prosecution, which can only be carried out in presence of a Security Council resolution authorising such an investigation. In addition to this, this article highlighted that the crime of trafficking is not explicitly criminalised in the Rome Statute as such and its qualification as 'sexual slavery' or 'enslavement' is ambiguous since it does not fully respect Article 21(3) of the Rome Statute. Despite this, the interpretation of these crimes could be expanded to include the crime of trafficking for the purpose of sexual exploitation, in line with the Rome Statute and the Elements of Crimes. However, the ICC has not yet prosecuted anybody for trafficking despite the existence of evidence on this crime in some of the states under investigation. Thus, it was suggested to modify the legal framework accordingly and, more specifically, to encompass, among the crimes against humanity, the crime of trafficking also for the purpose of sexual exploitation.

In conclusion, neither the domestic criminal law framework nor the ICC seem to be equipped to properly prosecute CRSV and trafficking and fully understand the nexus between the two. This is due to both legal and practical obstacles posed by the conflict situation and the lack of willingness by governments to make it a priority in their prosecution agenda. This is why this article suggests that it is important to keep pushing these 13 countries to improve their domestic legislation up to recognised international standards and the ICC to address the interpretative challenges posed by the crime of trafficking. Until CRSV and trafficking are recognised as an emergency in current days conflicts and their prosecution a priority for the international community, there will not be enough efforts to this extent.

\section{References}

Aston J.N., Trafficking of Women and Children: Article 7 of the Rome Statute (Oxford: Oxford University Press, 2016).

Ayeni V.O. \& Olong M.A., 'Opportunities and Challenges to the UN Security Council Referral Under the Rome Statute of the International Criminal Court', African Journal of International and Comparative Law 25 (2017), 239-260.

Chu S. K. H. et al., Survivors of Sexual Violence in Conflict: Challenges in Prevention and International Criminal Prosecution in Victimological Approaches to International Crimes: Africa, ed. R.Letschert et al. (Antwerp-Oxford: Intersentia, 2011), 527-560.

Chuang J., 'Redirecting the Debate over Trafficking in Women: Definitions, Paradigms, and Contexts', Harvard Human Rights Journal 11 (1998), 65-107.

Cryer R. et al., An Introduction to International Criminal Law and Procedure (Cambridge: Cambridge University Press, 2007). 
De Brouwer A., 'The Importance of Understanding Sexual Violence in Conflict for Investigation and Prosecution Purposes', Cornell International Law Journal 48.3 (2015), 101 131.

De Brouwer A., Supranational Criminal Prosecution of Sexual Violence: The ICC and the Practice of the ICTY and the ICTR (Antwerp-Oxford: Intersentia, 2015).

Galand A.S., 'Security Council Referrals to the International Criminal Court as QuasiLegislative Acts', Max Planck Yearbook of United Nations Law, 19 (2015).

Gallagher A. \& Holmes P., 'Developing an Effective Criminal Justice Response to Human Trafficking: Lessons from the Front Line', International Criminal Justice Review 18 (2008), 318-343.

Hall C.K., Powderly J. \& Hayes N., 'Article 7' in Rome Statute of the International Criminal Court: a commentary, ed O. Triffterer (Munich: G.H. Beck, Hart, Nomos, 2015): 144-294.

Hehir A. \& Lang, A., 'The Impact of the Security Council on the Efficacy of the International Criminal Court and the Responsibility to Protect', Criminal Law Forum, 26 (2016), 153-179.

Houge A.B. \& Lohne K., 'End Impunity! Reducing Conflict-Related Sexual Violence to a Problem of Law' Law \& Society Review 51.4 (2017), 755-789.

Hughes D.M., 'The "Natasha" trade: The transnational shadow market of trafficking in women', Journal of International Affairs 53.2 (2000): 1-18.

Human Rights Watch, Report on Libya, https://www.hrw.org/sites/default/files/reports/libya0114ForUpload_0.pdf (latest accessed on 26 october 2018 ).

Jalloh C.C., 'The African Union, the Security Council and the International Criminal Court' in The International Criminal Court and Africa, ed C.C. Jalloh \& I. Bantekas (Oxford: Oxford University Press: 2017), 181-213

Josse, E., 'They Came with Two Guns: The Consequences of Sexual Violence for the Mental Health of Women in Armed Conflicts', International Revue of the Red Cross 92 (2010): 177-195.

Kandiwal W.M., A Mapping Study: Institutional Mechanisms to Tackle Trafficking in Persons in Afghanistan, AREU Policy Note, March 2018.

Klabbers J., 'Just Revenge? The Deterrence Argument in International Criminal Law' Finnish Yearbook of International Law 12 (2001), 249-267.

Knottnerus A.S., 'The Security Council and the International Criminal Court: The Unsolved Puzzle of Article 16', Netherlands International Law Review 61 (2014): 195-224.

Kuwer P. et al., 'Long Term Effects of Conflict-Related Sexual Violence Compared with Non-Sexual War Trauma in Female World War II Survivors: A matched Pairs Study', Archives of Sexual Behaviour 43.6 (2014), 1059-64.

Lattmann T., 'Situations Referred to the International Criminal Court by the United Nations Security Council - Ad Hoc Tribunalisation of the Court and its Dangers', Pecs Journal of International and European Law 2 (2016): 68-78.

Mallory S.L., Understanding Organized Crime (Criminal Justice Illuminated), (Sudbury: Jones \& Bartlett Publishers, 2007).

Marcus M., 'Investigation of Crimes of Sexual and Gender-Based Violence Under International Criminal Law' in Sexual Violence as an International Crime: Interdisciplinary Approaches, ed A. de Brouwer et al. (Antwerp: Intersentia, 2013), 211-242.

McGoldrick D., 'The Permanent International Criminal Court: An End to the Culture of Impunity?’ x Criminal Law Review (1999), 627-655. 
Ní Aoláin, F., On the Frontlines: Gender, War, and the Post-Conflict Process (Oxford: Oxford University Press, 2012).

Office of the Prosecutor, Fifteen Report of the Prosecutor of the International Criminal Court to the United Nations Security Council Pursuant to UNSCR 1970 (2011), 9 May 2018, 33.

Organisation for Security and Co-operation in Europe, Combating Impunity for ConflictRelated Sexual Violence in Bosnia and Herzegovina: Progress and Challenges (June 2015).

Organisation for Security and Co-operation in Europe, Towards Justice for Survivors of Conflict-Related Sexual Violence in Bosnia and Herzegovina: Progress before Courts in BiH 2014-2016 (2017).

Payam A., 'Beyond Impunity: Can International Criminal Justice Prevent Future Atrocities?' American Journal of International Law 95.1 (2001), 7-31.

Prosecutor v Al Bashir, 'Warrant of Arrest for Omar Hassan Ahmad Al Bashir', ICC02/05-01/09-1, Pre-Trial Chamber I, 4 March 2009.

Prosecutor v Al-Bashir, Second Decision on the Prosecutor's Application for a Warrant of Arrest, ICC-02/05-01/09, 12 July 2010.

Prosecutor v Al-Tuhamy Mohamed Kaled, Warrant of Arrest for Al-Tuhamy Mohamed Khaled with under seal and ex parte Annex, Pre-Trial Chamber I, ICC-01/11-01-13-1, 24 April 2017.

Prosecutor v Harun and Kushayb, ' Warrant of Arrest for Ahmad Harun', ICC-02/0501/07-2, Pre-Trial Chamber I, 27 April 2007.

Prosecutor v Hussain, Warrant of Arrest for Abdel Raheem Muhammad Hussain, ICC02/05-01/12-2, Pre-Trial Chamber I, 1 March 2012.

Prosecutor $v$ Katanga and Ngudjolo, Decision on the Confirmation of Charges, PreTrial Chamber I, ICC-01/04-01/07-717, 30 September 2008;

Prosecutor v Katanga, 'Judgement Pursuant Article 74 of the Statute', Trial Chamber II, ICC-01/04-01/07-3436-tENG, 20 April 2015.

Prosecutor $v$ Kony et al, warrant of Arrest for Joseph Kony Issued on 8 July 2005 as Amended on 27 September 2005, Pre-Trial Chamber II, ICC-02/04-01/05-53, 27 September 2005.

Prosecutor $v$ Ntaganda, Decision Pursuant to Article 61(7)(a) and (b) of the Rome Statute on the Charges of the Prosecutor Against Bosco Ntaganda, Pre-Trial Chamber II, ICC01/04-02/06-309, 9 June 2014.

Prosecutor v Ntaganda, ICC-01/04-02/06-309, 36. Prosecutor v Katanga and Ngudjolo, Decision on the Confirmation of Charges, Pre-Trial Chamber I, ICC-01/04-01/07-717, 30 September 2008.

Request under Regulation 46(3) of the Regulatsions of the Court, 'Decision on the "Prosecution's Request for a Ruling on Jurisdiction under Article 19(3) of the Statute", ICCRoC46(3)-01/08-37, Pre-Trial Chamber I, 6 September 2018.

Sillers N., 'Modern Slavery: Does International Law Distinguish between Slavery, Enslavement and Trafficking', Journal of International Criminal Justice 14 (2016), 405-427.

Sivakumaran S., 'International Humanitarian Law' in International Human Rights Law, ed D. Moeckli, S. Shah and S. Sivakumaran (Oxford: Oxford University Press, 2010), 521539.

Tavakoli N., 'A Crime that Off ends the Conscience of Humanity:A Proposal to Reclassify Traffi cking in Women as an International Crime' International Criminal Law Review 9 (2009): 77-98. 
United Nations Security Council, Security Council Resolution 1593 (2005) [on Violations of International Humanitarian Law and Human Rights Law in Darfur, Sudan], 31 March 2005, S/RES/1593 (2005).

United Nations Security Council, Security Council Resolution 1970 (2011) [on establishment of a Security Council Committee to monitor implementation of the arms embargo against the Libyan Arab Jamahiriya], 26 February 2011, S/RES/1970 (2011).

United Nations, Report of the Secretary General on conflict-related sexual violence, S/20014/181, 13 March 2014.

United Nations, Report of the Secretary General on conflict-related sexual violence, S/2018/250, 23 March 2018.

US Department of State, Office to Monitor and Combat Trafficking in Persons, Trafficking in Persons Report 2017: Somalia country narrative.

Viseur-Sellers P., 'Gender Strategy is Not a Luxury for International Courts', Amsterdam University Gender Social Policy and the Law 17 (2009): 327-335.

Wheaton E.M., Schauer E.J. \& Galli T.V., 'Economics of Human Trafficking', International Migration 48.4 (2010), 114-141.

Zimmermann A., 'Two Steps Forward, One Step Backwards? Security Council Resolution 1593 (2005) and the Council's Power to Refer Situations to the International Criminal Court', in Common Values in International Law: Essays in Honour of Christian Tomuschat, ed P. Dupuy et al. (Kehl: Engel, 2006), 681-705. 